Au point de vue forestier, l'erreur commise a été de ne s'occuper que de retiser certains revenus immédiats sans prévoir pour l'avenir. Ce n'est malheureusement que la répétition, sur une plus petite échelle, de ce qui se fait par les grandes compagnies forestières.

$4^{\circ}$ - Les villes et les cités devraient être encouragées à améliorer leurs parcs et les terres boisées achetées pour protéger les réservoirs ou sources d'eau.

$5^{\circ}$ - Des efforts devraicnt être faits auprès des directeurs des Universités pour. l'achat de certaines superficies boisées où les étudiants en foresterie pourrajent mettre en pratique les théories puisées dans les écoles forestières.

$6^{\circ}$-Les Sociétés d’Ingénieurs Forestiers devraient demander aux écoles d'agriculture d'accorder plus de cours sur l'entretien d'un lot boisé et sur les manières de procéder.

$7^{\circ}$ - Un pamphlet illustré devrait être préparé sur la nécessité de la conservation d'un lot boisé et expliquer les différentes manières de faire un trạvail méthodique. Ce pamphlet qui devrait être répandu dans toutes les provinces, devra donner les renseignements sur le mesurage des bois debout et débités, sur le marché des produits forestiers, la valeur calorifique et les propriétés mécaniques de chaque espèce de bois aussi bien sur la manière do faire un élagage et des coupes judicieuses.

Les bulletins et pamphlets devraient être imprimés dans les deux langues officielles, en français et en anglais, afin de permettre à chacun de se renseigner facilement.

Signé:

$$
\begin{aligned}
& \text { J.-A. ROY, i.f. } \\
& \text { Président, Québec. } \\
& \text { I. C. MARRITT, } \\
& \text { Secrétaire, Toronto. }
\end{aligned}
$$

\title{
REPORT ON FOREST FIRE HAZARD RESEARCH
}

By the Sub-Committee of the Forest Reserarch Co-operative Committee of the Canadian Society of Forest Engineers

Presented at the Annual Meeting of the Society in Ottawa, January 13 and 14, 1936

The Sub-Committee on Forest Fire Hazard Research is composed of the : following personnel:

H. Methot, Chairman

J. G. Wright, Secretary 


\title{
FORESTRY CHRONICLE
}

\author{
H. W. Beal]
}

R. Bellefeuille

The report summarizes the progress which has been made on this study to date and suggests ways in which it may be further advanced. The Report follows:

Forest authorities have for many years recognized the desirability of some accurate method of measuring the degree of forest inflammability which exists each day during the fire season. While old and experienced fire-fighters no doubt know with a fair degree of precision when periods of fire danger are upon them, it is impossible by experience alone to state definitely the degree of danger which prevails from day to day. In the case of more or less inexperienced men, who, in the average organization, probably far outnumber the veterans, the necessity for some scientific means to measure fire danger is apparent, if fortst fire protection is to be carried out with a minimum of fire costs and timber loss.

\section{EARLY STUDIES}

The subject of forest fire hazard research first began to receive attention some eighteen years ago. The early investigators stressed the importance of relative humidity of the air as a criterion of fire danger. Relative humidity is am important factor particularly in those coniferous types which bear moss on the branches. In periods of high humidity the moss heing highly hygroscopic, will absorb atmospheric moisture and so reduce the tendency for crown fires to spread. In most forest types, however, relative humidity alone can at best provide only an indifferent measure of the daily degree of fire hazard, as the fuels do not instantly respond to changes in humidity and other factors enter to. complicate the subject.

\section{GISBORNE SYSTEM}

Gisborne in the north-western states has made probably the most outstanding contribution to the study of fire lazard. He based the measurement of forest inflammability upon the moisture content of the actual forest fire fuels, and with associates at Madison, developed the duff hygrometer for measuring the moisture content of forest litter. Later he developed a "fire danger meter" by means of which it is possible to combine several factors such as moisture content of the fuels, season of the year, wind velocity, accessibility of an area, prevalence of fire starting agencies, etc. The duff hygrometer is a somewhat difficult instrument to operate and in recent years Gisborne has developed the use of wood cylinders of known oven dry weight, exposed in a standard manner in the forest, for the purpose of estimating fuel moisture content. While detailed information is not at present available to your committec, it is understood that wood cylinders are being used with success in British Columbia. 
At the Petawawa Forest Experiment Station of the Doininion Forest Service, experiments have been carried on since 1929 on the use of changes in weight of various hygroscopic materials exposed in a standard manner as a guide to forest inflammability. These experiments included dead twigs and branch wood, moss, dead fern, cellucotton, wood cylinders and untreated match splints. The last two inaterials were the only ones which showed any prospects of practical success and the match splints, as a rule, were found the better of the two. The principal objections to the use of match splints or wood cylinders or rectangles are as follows:

(a) The rate of drying varics with the site and exposure so that it may be difficult to locate a representative site near at hand.

(b) The changes in moisture content do not agree directly with the changes in the litter on the forest floor, and for hest results a correlation curve must be prepared from actual observations.

(c) These materials may indicate the day inflannmability begins, but cannot be relied upon to indicate definite degrees of inflammability after that date.

(d) All these materials lose weight from weathering and decay during the season and for best results a progressive correction factor for this must be applied.

(e) It is impossible to apply a weather forecast to this method so as to forecast the probable hazard within the next two days.

The method, however, has the advantage of simplicity and is vastly better than depending on individual judgment alone.

\section{NICHOLS' SYSTEM}

The same criticism applies to the method used by Nichols in Quebec sone years ago, in which use was made of changes in weight of a basket of full layer duff in place on the forest floor. This latter method, however, possesses an additional source of error in that the inflammability point of top layer duff may occur at a wide range of basket moistures, depending upon the drying conditions.

\section{STICKEL SYSTEM}

Stickel in the north-eastern states has developed a system of fire hazard measurement using certain controlling weather factors as a basis. The degree of hazard is obtained from an alinement chart using the following factors: number of hours since last measurable rainfall, air temperature and relative humidity. In some alinement charts rate of evaporation is used instead of relative humidity. In the forest types for which the alinement charts have been prepared, Stickel reports a satisfactory degree of accuracy by this method. It will be noted, however, that the system does not take into account the amount of rain 
and that for purposes of the chart heavy rains of one inch or more are given no greater weight than light showers of one one-hundredth of an inch. It also takes no account of the moisture condition of the forest at the time the last rain began. It is definitely known that the effect of a given amount of rain in reducing: forest inflammability depends greatly upon the moisture condition of the forest fire fuels before the rain started.

\section{IVRIGHT SYSTEM}

The system of fire hazard measurement which has gained the widest use in Canada was developed at the Petawawa Forest Experiment Station of the Dominion Forest Scrvice and users of the system refer to it as the Wright System. It, like the Stickel system, depends upon the correlation of critical weather factors with the inflammability of each forest type. Over a period of years the wetting effect of rain has been observed in the types studied, due consideration being given to amount and duration of rain, as well as to the moisture condition of the forest before each rain started. The rate of drying after rain is measured by the daily rate of evaporation of water from a simple instrument now known as the Wright evaporimeter. Evaporation is used as a guide to fuel moisture loss down to the point where surface duff becomes inflammable. From this point on the fuels may gain or lose moisture depending on whether the relative humidity of the air is high or low. During this stage, use is made of both relative humidity and evaporation to trace the fluctuations of fire hazard from day to day.

From the observed data an index of inflammability has been developed for the types studied. The information is available in the torm of tables. By the aid of these tables it is possible to compute the effect of any given rain in reducing the index of inflammability. After the rain stops the tables enable the forest officer to compute the rise in the index each day, using the daily measurement of evaporation as a guide. When the index has risen to the region of low inflammability, the tables, by the use of both relative humidity and evaporation records, enable the hazard to be traced through "low," "medium," "high" and "extreme."

The only tables so far produced are for the pine types of eastern Ontario and western Quebec. A practical test of the accuracy which may be expected in fire hazard charts computed from these tables has been made, using as data all fires which occurred within the weather zone of the Petawawa Forest Experiment Station over a five-year period. The charts were found to possess an accuracy as to the occurrence and behaviour of fires of $96 \pm 1$ per cent including lightning fires. If incipient lightning fires, which may start in dead "stubs" even during rain, are omitted from the analysis, the accuracy shown is $99 \pm 1$ per cent. 
In addition to the pine types studied, for which fire hazard tables have been developed, data have been collected for hardwood forests, mixed wood forests and open grassy types at Petawawa. Some of these data will be made available for practical use next season.

Beall of the Dominion Forest Service has developed a simple formula which is used in conjunction with the Wright System for finding the average index of hazard in a forest area composed of several forest types. In this formula due weight can be given to all factors contributing to fire danger, such as:inflammability of each type, proportionate area and value of each type, accessibility, and prevalence of fire-starting agencies.

The Wright System is now in wide use in the province of Quebec where it has been adopted after careful tests by the Forest Protection Service. Several private forest authorities in that province have been using the System for a numher of years and report it reliable, accurate, and of value in their protection work.

\section{NEW $\subseteq T U D I E S$}

The most pressing need at present in the province of Quebec is for data suitable to the spruce-balsam forests. To secure the necessary data the Province has established a fire hazard research station at Duchesnay. Research work on spruce-balsam forests is being carried on here in close co-operation with a similar station of the Dominion Forest Service at the Valcartier Forest Experiment Station. Work at these two stations was begun in 1935 .

The results obtained at Duchesnay and Valcartier during the past summer indicate the necessity for certain field studies to interpret and verify the experimental work conducted at the stations. These field studies comprise the following:

(1) The study of actual large fires in spruce-balsam.

(2) The study of actual abatis or slash fires.

The Forest Protection Service of Quebec is anxious to advance research by offering co-operation in the following ways:

(1) (a) To enable trained observers to visit going fires to gather data on conditions conducive to crown fires, and spot fires ahead of the main fire.

(b) To provide facilities for the study of "burns" shortly after the fire.

(c) To gather data by questionnaire from experienced fire fighters.

(d) To provide facilities to conduct experimental fires on a natural scale uInder varying weather conditions on specially prepared sample areas, preferably on an island.

(2) (a) To enable trained observers to be present while settlers' slash is heing burned under the supervision of officers of the Service. 
(b) Generally, to provide facilities to enable observers, by experiment, to establish rules for the piling and burning of slash.

Your committee is of the opinion that the foregoing projects, if carried out, will provide much new, valuable and highly practical data on fire hazard. It wishes to stress, however, the necessity of employing only specially trained men as observers. These projects will also involve some expenditure of funds, and it is urged that the authorities interested provide the necessary appropriations to carry the work to a successful conclusion.

\section{WEATHER FORECASTS}

While a knowledge of the actual degree of hazard which exists day by day is of great value, it would be still more desirable if the hazard could be prodicted with accuracy one or more days ahead. During the past two years the index of fire hazard at Petawawa has been predicted one day ahead with a fair degree of accuracy. This was accomplished by using a weather forecast in conjunction with the fire hazard tables. Naturally the accuracy of the hazard forecast depends to a large extent upon the accuracy of the weather forecast and unfortunately it appears difficult to secure accurate localized forecasts from the Meteorological Office in Toronto.

At Petawawa it has been found that with the aid of suitable weather instruments and an idealized or theoretical weather map showing the combination of weather factors associated with pending weather changes, it is possible for an experienced observer to provide a local weather forecast at least as accurate as the more general official forecast. This is an important discovery when it is remembered that the official daily weather maps usually do not reach forest stations until they are a day or more old. This method of weather forecasting was used at Valcartier during the season of 1935 and the average accuracy of the 24 hour fire hazard forecasts hased upon these weather forecasts was found to be within one zone of fire hazard 95 per cent of the time.

The Meteorological Service has always shown every desire to co-operate with forest authorities, and has provided a large amount of equipment for use in forest areas. It occurs to your committee, that by suitable instruction to skilled forest weather observers, the Meteorological Service might be able to improve the accuracy of localized weather forecasts. In many areas improved local weather forecasts would be valuable to other interests besides forest authorities. Many cases are on record in the province of Quebec where farmers consult forest officers at weather stations to determine if wet or dry weather is expected and govern their hay cutting and other activities accordingly. In this Province where many fires start from settlers clearing land, the close contact thus afforded between forest officer and settler should make for better feeling, closer co-operation and a consequent reduction in settlers' fires. 


\section{GENERAL}

While excellent results have been attained in practical use of the Wright System of fire hazard measurement, it is believed that it would have a still wider application if it could be further simplified without sacrifice of accuracy. Every effort should be made to present all data for field use in the simplest possible form.

Consideration should be given by forest authorities to fuller uses which may be made of the system in order that the maximum savings may be effected through its use.

At Petawawa last season, experiments were conducted on the use of 20 per cent solution of calcium chloride in water for use with hand fire pumps in fighting grass fires. The sprayed guards remain wet until rain comes. It is recommended that further research be carried out, preferably in co-operation with the Research Council, on the use of inexpensive chemicals in fire suppression.

There is great need for special equipment and apparatus in fire hazard research. Owing to hitherto limited appropriations much of the equipment used has been of the most primitive nature and the degree of progress made in spite of this handicap is rather remarkable. The most pressing need at present is for some means of accurately measuring the intensity of test fires under varying conditions in order that they may be compared. It is recommended that this and other instrumental problems be referred to the Research Council for solution.

Finally your committee is of the opinion that excellent and valuable work is being done in Canada on forest fire research and that the fullest financial support should be accorded to those engraged in this work.

\section{Respectfully submitted,}

H. МЕтнот, Chairman

J. G. WRIGHT, Secretary

\section{REPORT ON THE SUB-COMMITTEE ON FOREST ENTOMOLOGY OF THE CANADIAN SOCIETY OF FOREST ENGINEERS}

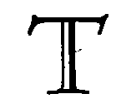

HE FINAL organization of the Sub-committee on Forest Entomology was deliberately delayed until some time after the conference on Forestry Research which was held at Ottawa in November. Rumours of the formation of a new Research Committee, under the auspices of the Research Council, were heard at the time of the summer meeting of the 